\title{
Queering the archive Amateur films and LGBT+ memory
}

\author{
Dagmar Brunow
}

A film clip on Vimeo shows two women on the American coast, climbing onto a ship pulled up on the shore and then scrambling on some rocks. ${ }^{1}$ This home movie from 1938 features New York schoolteacher Ruth Storm (1888-1981) and a friend visiting Maine, where Storm would later retire with her last lover Almeda ('Meda') Benoit. ${ }^{2}$ From the mid-1930s to the mid-1960s Storm had been filming her life, mostly on $16 \mathrm{~mm}$ film. Almost 80 years after it was filmed, this sequence was made available to global audiences. Setting out 'to seek, preserve, document, and screen amateur home movies shot by or depicting lesbians', the Lesbian Home Movie Project (LHMP) in Maine has embarked on a memory project with the potential to rework LGBT+ heritage and regional memory alike. ${ }^{3}$

Everyone needs memories to create their identities. Although these rare early lesbian home movies can be a precious addition to audiovisual memory, only a small number of them will survive (audiovisual memory here being the sum of images, sounds, and narratives circulating in a specific society at a specific moment). Their preservation is urgent because these films diversify cultural memory by offering previously unheard stories. As analogue footage is decaying, digitization has not only been used for the purpose of preservation and restoration, but also to create access to films via online exhibition. ${ }^{4}$ 


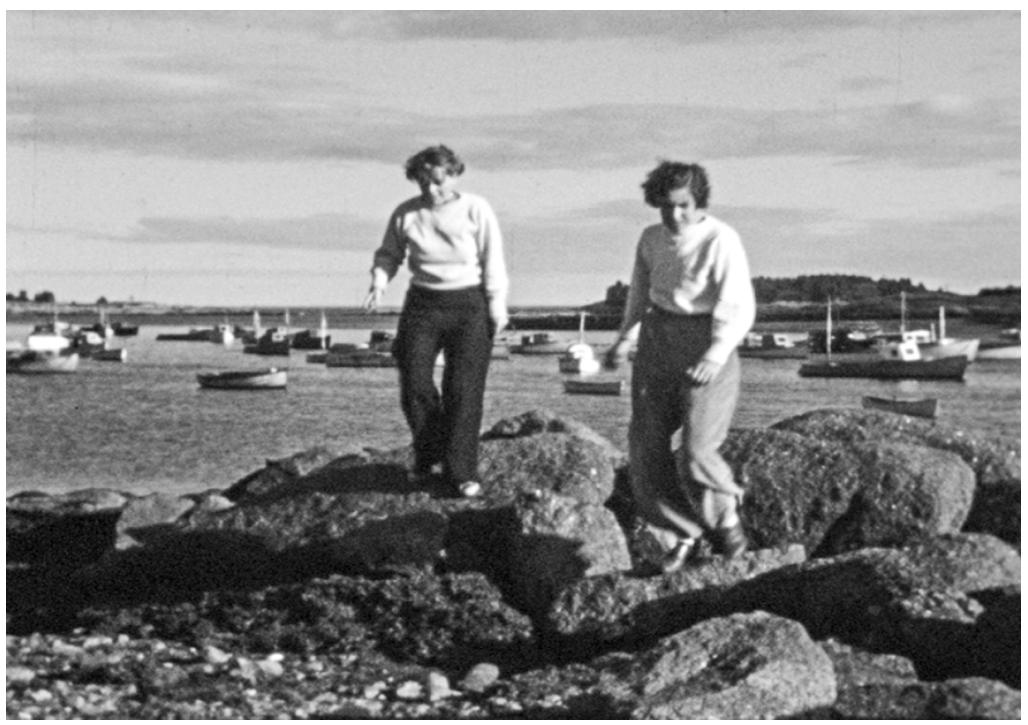

Figure 4.1. Chenoweth Hall and Ruth Storm at Corea, Maine, in the late 1930s. Courtesy of the Lesbian Home Movie Project, Maine.

Archival practice can intervene in a film historiography that has obscured the agency of women as filmmakers. At the same time, it raises questions about queer visibility in the archive. Lesbian home movies can be found in private homes, in moving image archives, mixed-media archives, and in LGBT+ archives, for example grassroots or community archives, but their lesbian production or exhibition context may be obscured by cataloguing and metadata. ${ }^{5}$ Unless a context is provided by the archivist, silent home movie images alone would hardly give away that they depict lesbian lives. The same goes for lesbian home movies found at auctions, jumble sales, or flea markets. Too often the footage runs the risk of being 'read' through a heteronormative perspective which erases the lesbian content, for example by turning lovers into good friends or colleagues. Once the personal memories have entered the public sphere, for whatever reason, 'lesbian signifiers become all but impossible to read, let alone prove', as Sharon Thompson, founder and executive director of the LHMP, reminds us. ${ }^{6}$ This is 
why a lack of contextualization might lead to forgetting. In this case the film will be lost to LGBT+ heritage. The question is how archival practice can diminish the risk of unqueering the footage, especially in the context of online exhibition. Still, the archival practice of creating access is of vital importance, as a film needs to stay in circulation to be remembered and to become part of LGBT+ heritage. A film which is confined to the shelves will easily be forgotten. Since memories are created in the process of reception, and through the narratives thus evolving, archives need to create access to their audiovisual material. Digitization can contribute to archival outreach since it allows for the circulation of films to an unprecedented extent. Yet, access cannot be provided to all of the content due to legal or ethical considerations as well as lack of resources. ${ }^{7}$ The shift from a private viewing context to the public sphere, meanwhile, implies new challenges for the preservation of LGBT+ heritage.

This essay argues for the urgency of lesbian home movie preservation, examining the challenges involved when curating access to the collections and, in doing so, exploring the relationship between archival practice, audiovisual memory, and LGBT+ heritage. Its purpose is to contribute to the growing research on queer archives, but it also acknowledges the media specificity of moving image archiving. ${ }^{8}$ While research on moving image archives tends to neglect specific questions of archiving LGBT+-related films, studies on queer archives often ignore the specific requirements involved when archiving audiovisual footage. Notable exceptions are oneoff journal articles by US-based archivists, such as Lynne Kirste, Special Collections Curator at the Academy Film Archive; Kristin (KP) Pepe who became involved in the Outfest Legacy Project; and Sharon Thompson, director of the Lesbian Home Movie Project. These archivists have offered important insights into the challenges of archiving LGBT+-related film stock, but we need more research that brings together questions of the archive and its fundamental role in the creation of audiovisual memory and LGBT+ heritage. ${ }^{9}$ Therefore, this essay will examine three archival interventions 
against forgetting: collecting, circulating, and contextualizing. To start with, let us first tease out the relationship between memory and the archive.

\section{Minor cinema, memory and heritage}

Lesbian home movies and amateur films challenge the gendered and sexual norms of archival visibility. ${ }^{10}$ Despite the fact that home movies follow generic conventions and are performative acts just like all forms of documentary film-making, the truth claim for home movies has been strong. ${ }^{11}$ Home movies have therefore been acknowledged as a historical source. ${ }^{12}$ From this perspective, the strength of lesbian home movies lies in their capacity to offer a window into the past, 'into ordinary LGBT life, what we did, how we lived, our homes, vacations, hobbies, pets, parties, friends, and all that is often invisible in film history', as Kirsten (KP) Pepe states. ${ }^{13}$ Likewise, as Sharon Thompson notes, the footage archived at the Lesbian Home Movie Project conveys glimpses of everyday life by depicting 'lesbian life outside of the bars documented to date: Lesbianism on vacation. Lesbianism in the front yard. Lesbianism on the ball field.' ${ }^{14}$ As a means of self-fashioning, home movies and amateur films have the capacity to counter stereotypical media representations and to carve out discursive spaces for queer lives. Early lesbian home movie footage diversifies the audiovisual memory of LGBT+ lives before Stonewall, a memory from which images of everyday queer lives were excluded. Home movies and amateur film-making can offer fresh perspectives of LGBT+ pasts beyond dominant representations framed by criminalizing discourses, such as images of raids and police surveillance.

Highlighting the role of the archivist requires a theoretical shift from the notion of the 'archive' to the process of 'archiving. Contesting the alleged neutrality and objectivity of the archive, Michel Foucault's, Jacques Derrida's, and Ann Laura Stoler's theorizations have resulted in a paradigmatic turn from the storage of knowledge to its production. ${ }^{15}$ The archive is 'a space where queer subjects 
put themselves together as historical subjects, even if done in the context of archival lack. ${ }^{16}$ As an agent in its own right, the archive has been theorized as a process in which knowledge and facts are continuously recreated and transformed, but archives are nothing without their archivists, who provide a framework for the interpretation of the holdings. As Jack Halberstam claims, archives need 'users, interpreters, and cultural historians to wade through the material and piece together the jigsaw puzzle of queer history in the making. ${ }^{17}$ Archivists construct archival records through practices such as collecting, selecting, discarding, and cataloguing. They apply metadata to describe and categorize the archival holdings for the purpose of making them searchable-and findable. Choosing adequate terms for catalogue entries, keywords or tags is even more important in times of digitization as the searchability of digitized content is dependent on its metadata. In this process the archivist becomes a memory agent whose work feeds into audiovisual memory. If we understand the archive as the foundation from which history is written, cultural memory can only become polyvocal and diverse if the archive creates multiple narratives and images. Archivists are therefore agents who can contribute to renegotiating audiovisual memory - they do not determine, but can influence whether it will be perpetuated or subverted.

A research perspective situated on the margins can indicate which voices are missing from cultural memory. It provides a useful tool for examining the centre, and the exclusions the centre produces. Therefore, the notion of 'minor cinema' can be useful. Drawing on Deleuze and Guattari's notion of 'minor literature', it has been used in film studies to highlight the power relations inherent in film production, distribution, and exhibition. ${ }^{18}$ It is a concept not to be understood in binary terms of a counter-cinema practice, but as a relational mode. I would argue it can be adapted to archival practice by employing the term 'minor archives'. The expression 'minor archives' can be used as an umbrella term for archives with a specialist collection policy, dedicated to foregrounding the omissions often found in national archives, such as feminist herstory archives, 
Black or other ethnic minority archives, or LGBT+ archives. Minor archives can be regarded as interventions into the omissions and exclusions produced in the process of archiving. Minor archival practice can add to the polyvocality of cultural memory. ${ }^{19}$ In my recent research project, 'The Cultural Heritage of Moving Images', financed by the Swedish Research Council (2016-2018), I examine ways of curating access within film archives in the wake of digitization and diversity politics. While I study national film archives in Europe, especially the collections administered by the Swedish and the British film institutes, I argue that in order to create polyvocal audiovisual memories, national film archives could profit from the work and expertise of minor archives.

This essay draws on two minor archives that are examples of best practice: the Lesbian Home Movie Project (LHMP) in Maine and bildwechsel in Hamburg. The LHMP was founded by Mainebased writer and archivist Sharon Thompson along with film critic B. Ruby Rich, based in San Francisco and professor at the University of California at Santa Cruz, and Kate Horsfield, founder of the Chicago Video Data Bank. The project's existence is inextricably linked to the discovery of Storm's home movies after the death of Storm's last lover Meda in 2009. During the LHMP's archival work with the Ruth Storm collection, today consisting of eighteen $16 \mathrm{~mm}$ reels, more home movie collections surfaced, adding up to 20 analogue film and videotape collections, which have been digitized by the LHMP. In order to deepen the understanding of the archival work accomplished by the LHMP I also draw on the feminist archive bildwechsel, based in Hamburg in Germany. ${ }^{20}$ bildwechsel was founded in 1979, and, dedicated to video work by and about female artists and filmmakers, its archival practice aims at representing women and transgender artists in general, regardless of their sexual orientation. To date, bildwechsel has collected more than 8,000 videos, the majority of which are still on analogue stock, ranging from works by Agnès Varda, Chantal Akerman, Monika Treut, and Martha Rosler to artists' interviews, experimental film-making, documentary films, and video diaries. 


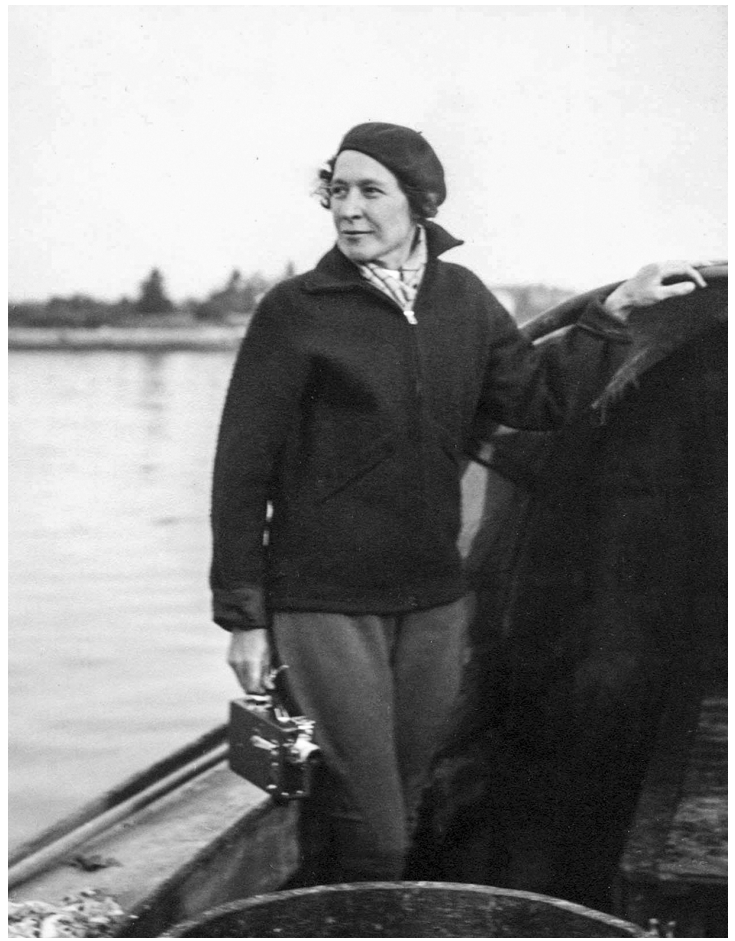

Figure 4.2. Ruth Storm with her Cine Kodak Model $\mathrm{K}$, date unknown. Courtesy of the Lesbian Home Movie Project, Maine.

If we compare the self-fashioning of the LHMP archive with that of bildwechsel, we could argue that the LHMP, in its name and scope, foregrounds (sexual) identity politics, whereas bildwechsel situates itself in the context of feminist (but trans-inclusive) separatism.

\section{Collecting: into the archives, onto the shelves?}

Lesbian home movies and amateur film-making, like other forms of minor cinema, are often on neglected formats, such as video, $8 \mathrm{~mm}$, or $16 \mathrm{~mm}$. While the earliest home movies in the LHMP's collections date back to the 1930s, video allowed easier and cheaper access to film-making in the 1970s, with archival works documenting pride 
parades, activist gatherings, or women's music festivals. Though based on the will to remember, archival operations include the dimension of forgetting too, as the material collected, preserved, and restored is only a small fraction in comparison to what has been lost. Lesbian home movies could be forgotten for various reasons. Where they remained with the filmmaker until her death, the films might have been destroyed or discarded by homophobic relatives. Another crucial factor, already mentioned, is the ongoing decay of the analogue film stock. Sharon Thompson of the LHMP reminds us of the fragility of home movies, for 'Their media are easily damaged: heat, humidity, dust, and time are major issues.'21 Decay is accelerated even further if the footage is not stored in climate-controlled vaults, but kept in inadequate conditions in private homes, in attics, on shelves, or under beds. Even if reels or tapes survive, they need to be screened if they are not to be forgotten. Analogue gauge requires equipment that is able to project $8 \mathrm{~mm}$, super $8,16 \mathrm{~mm}$, or outdated video formats. As such equipment is lacking in many homes and archives, a substantial amount of lesbian home movies and amateur films will be lost forever. Archivists have therefore been reaching out to LGBT+ communities, encouraging filmmakers to donate their home movies to film archives. ${ }^{22}$

Through collaborations, different archives can help each other retrieve queer histories: minor archives can profit from the resources provided by major archives, whereas major archives can draw on the knowledge created by the communities around minor archives. Access to climate-controlled vaults is but one of the challenges minor film archives are facing. As Lynne Kirste details, 'Climate-controlled storage, necessary to prevent deterioration of films and tapes, is typically out of reach financially, as are viewing equipment for more than one or two media formats. ${ }^{23}$ bildwechsel is a rare exception in providing the necessary video recorders required to play the 19 different video formats available in the archival collections. The LHMP collaborates with the Northeast Historic Film Archive in Bucksport, Maine, where it rents space for its analogue footage to be stored in climate controlled conditions. While such archival 
collaborations set out to counter the invisibility of LGBT+ lives, new challenges emerge when lesbian home movies start circulating in the heteronormative public sphere.

\section{From safe space straight into cyberspace?}

Cultural memory is never stable, but always in flux and constantly reworked. Films need to circulate to be remembered, as only their distribution and dissemination provide a context and framework for their reception. My conceptualization of memory as inextricably linked to circulation, rather than to archival storage, has been inspired by recent trends in memory studies. ${ }^{24}$ To become part of these circulating memories, films need to be freed from the confinements of the archive. Archival footage can be circulated in various ways, for example by public screenings or by reinserting it into other new film projects. Moreover, it can be uploaded for online exhibition on the archives' websites, YouTube, or Vimeo, and can thus reach out to worldwide audiences. This, in turn, has both legal and ethical implications. To illustrate, the LHMP screens selected films from its collections in queer or feminist contexts, such as gender studies classes, at conferences, film festivals or in friendship groups, provided the donors have agreed to public exhibition. Vimeo clips and photos are shared via a Facebook page that was established in 2012. Some of the footage has become part of the documentary Reel in the Closet (Stu Maddux, US 2015), which remediates home movies and other archival footage from a number of film archives and queer preservation projects. By making the footage available to global audiences, Reel in the Closet, which premiered at the Frameline San Francisco International LGBT+ Film Festival before touring the queer film festival circuit in the US and Europe, has become a travelling archive for queer memories. Moreover, the collaborative digitization project 'The Woman Behind the Camera: Home Movies and Amateur Film by Women, 1925-1997' by the LHMP, Northeast Historic Film and the Chicago Film Archives, enables online access to home movies 
or film clips from the collections on the homepage of the LHMP, launched in 2019. ${ }^{25}$

Home movie and amateur filmmakers have trusted LGBT+ archives as safe havens for their material, where it is taken care of in a context of affection and solidarity. ${ }^{26}$ Creating online access to footage once intended for private or semi-public viewing begs the question of whether this is an ideal solution, especially considering the fact that film-making individuals may originally have relied on the safe space provided by a lesbian minor archive. Handing over such 'archives of feeling', as Cvetkovich has it, in times when queer lives have only recently been de-criminalized or de-pathologized is still a matter of trust. It is doubtful that the private memories will be met with the same understanding once they have entered the public sphere through online exhibition. Moreover, online access can be hindered on legal grounds, such as property rights or personal rights. In Germany, where the legal concept of 'fair use' does not exist, music rights have often been the main barrier to the online exhibition of film heritage. Apart from legal issues, archives such as the LHMP or bildwechsel take ethical issues into account. Even if permissions for online exhibition have been granted by the donors, footage might not be uploaded if it is considered by the archivists to be too private for online circulation or problematic for other reasons. For instance, film images of nudity, especially toplessness, have become an issue for the archivists to address, as Sharon Thompson points out: 'In the feminist context of the time, going topless meant claiming the freedom men had always had. In a streaming context, many filmmakers and participants fear it being read, and used, as pornographic, a repugnant idea to many. ${ }^{27}$ Uploading or not uploading footage showing topless women at feminist separatist events, such as women's music festivals, involves decisions based on ethical considerations. Another challenge for the archivists comes from representations of acts that might address legal issues. As Sharon Thompson writes, 'some wholly public events in the tapes involved actions not strictly speaking legal; for example, a group going out late at night with spray cans of paint 
to emblazon a highway wall with feminist and gay slogans and symbols. Decades later not everyone wanted to flaunt what they'd done. ${ }^{28}$ For such cases, the LHMP often involves the donors and other contemporaries in the decision-making process.

As for the challenges to be faced when curating online access, the archival practice of bildwechsel can offer inspiration for other audiovisual archives. bildwechsel currently has three levels of access to its collections.$^{29}$ First, for the major part of the collections, access is granted to visitors on-site only. Second, regionally limited access might be possible for programmes curated by bildwechsel, for example in collaboration with the Hamburg Cinemathèque at the Metropolis cinema, or the International Queer Film Festival Hamburg. Third, only a very limited number of digitized videos are globally accessible online, after all the rights have been cleared. Neither bildwechsel nor the LHMP has a commercial interest in the footage, and they do not define themselves as distributors of the material, but, as archives, they also want to grant access to the films, albeit only on terms which are accepted by the individual rights holders. Both bildwechsel and the LHMP sign contracts with each of the rights holders, detailing to what extent, and to whom, the material should be available. Sometimes, the permission from the donor, creator, or participants is required before access is granted to the collection or part of it; in other cases, the filmmakers grant access on the premises of the archive only, or might agree to a limited distribution, for instance screenings arranged or curated by the archives. It can take several months of emailing back and forth before a final agreement is reached. However, apart from its obvious advantages of wide access, online exhibition does also involve the risk of making the queer content of the films invisible, unless it is specifically marked and framed as such.

\section{Out of the archives, into the closet?}

Since the traces of LGBT+ pasts have often been hidden or overwritten, the contextualization of film footage is a crucial task for archivists. As Patricia Zimmermann points out for home movies 
in general, 'signification is often not embedded inside the representation. ${ }^{30}$ Meanwhile, lesbian home movies might be even more complicated to handle because the lesbian content might be easy to miss. The main reason is the invisibility of lesbian loves and lives in the public sphere, closely related to the scarcity of lesbian media representation. Sharon Thompson emphasizes the difficulties of decoding lesbian signifiers: 'Two teenage girls doing the twist; a gaggle of young women playing volleyball; a flirtatious wink, a thrown kiss, a warm glance? Good luck finding someone at an estate auction able and willing to tell the inside story. ${ }^{31}$ It can therefore be of vital importance to prevent the material from being unqueered in viewing contexts that are not specifically marked as LGBT+-related. ${ }^{32}$

In private or semi-public exhibition contexts, lesbian home movies create audiences of queer kinship groups. These viewing contexts, in which the filmmaker and her close circle used to be present, have provided a framework of interpretation for the-often silent-film images projected. During the screening, members of the audiences tend to comment on the images and negotiate their meaning. As José Esteban Muñoz famously notes:

Queerness is often transmitted covertly. This has everything to do with the fact that leaving too much of a trace has often meant that the queer subject has left herself open for attack. Instead of being clearly available as visible evidence, queerness has instead existed as innuendo, gossip, fleeting moments, ... while evaporating at the touch of those who would eliminate queer possibility. ${ }^{33}$

Muñoz's ideas offer a fresh perspective on queer archival practice. Just like performance, which Muñoz focuses on, archival practice can have a performative impact on the construction of LGBT+ heritage by including those film images that do not offer any 'visible evidence' for a specific sexual identity. Still, they can be understood in terms of queerness as suggested by Muñoz, 'as a possibility, a sense of self-knowing, a mode of sociality 
and relationality. ${ }^{34}$ Contextualization provided by archivists can frame the meaning of films. While an act of unqueering might be a deliberate oppositional reading of the film images, a lack of contextualization does not have to be an intentional act, but could simply be the result of limited resources or a lack of priorities, as for example in heteronormative archives. However, an act of unqueering the film images results in an erasure of LGBT+ lives. To prevent LGBT + heritage from being overwritten, the LHMP puts an impressive amount of effort into the contextualization of its digitized archival holdings. The archivists conduct oral history interviews with those who have participated in the film production and with their partners and friends. The resulting information offers invaluable help for future users and researchers. Creating such contextual information around the archival footage provides a framework for the circulation and reception of these films and videos as LGBT+ heritage.

We should not forget that the archive itself, in its scope and intended audience, does offer a framework of interpretation for its users. An archive dedicated to LGBT+ heritage differs in this respect from general moving image archives, for as Kirste states, 'Researchers at LGBT archives begin searches knowing that every film or tape in the institution is queer-related, whether or not other cataloguing details exist in the archive's database. ${ }^{35}$ Likewise, we need to distinguish between different forms of online exhibition. On video streaming sites such as YouTube or Vimeo, the contextualization - the 'naming' - will have to be provided by the archivists who upload the footage for global circulation. They can decide to 'name' the LGBT+ context in the title they choose for the clip, as well as in the accompanying text, or in their choice of tags for each individual video clip. These algorithms will then continue to contextualize the clip-beyond the control of the archivist-by recommending other videos to watch. The videos thus provide an interpretative framework for users, which they can accept, oppose, or negotiate. ${ }^{36}$ The advantage of video-sharing websites such as YouTube or Vimeo is their global access, at least in theory, 


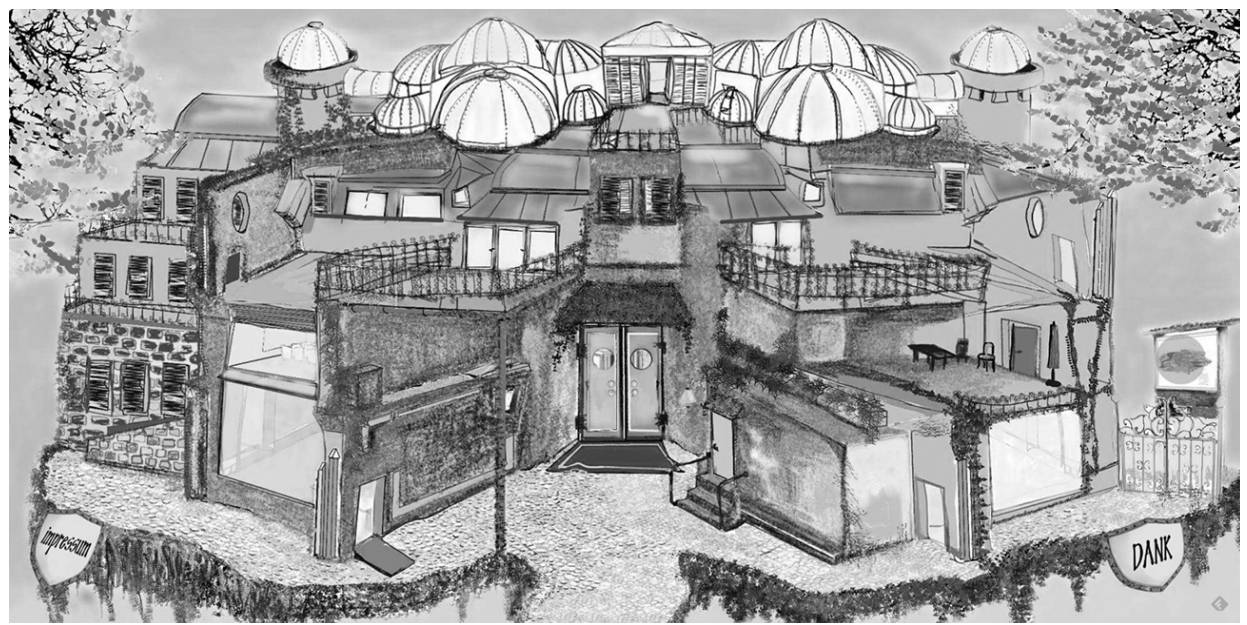

Figure 4.3. The video castle. Courtesy of durbahn, bildwechsel, Hamburg.

and the chance that the videos can be found, either intentionally or at random.

Highly sceptical towards YouTube due to its erratic upload policy, bildwechsel has created its own online exhibition tools for archival content. ${ }^{37}$ After experimenting with various online formats, bildwechsel launched its exhibition window, the video castle (Videoschloss) in 2016. ${ }^{38}$ Designed by bildwechsel co-founder, archivist and visual artist durbahn and programmed in-house by members of the bildwechsel team, the 'video castle' is constantly expanding. With its design reminiscent of both the Swedish-Finnish artist Tove Jansson's Moomin house and an old-fashioned computer game for kids, the video castle can be entered like an exhibition space or an art gallery. Via a lift the user moves between the different floors, with each floor offering a selection of videos, grouped by themes such as animation videos or videos documenting bildwechsel's own heritage. A clear link to the bildwechsel archives is established by the texts that accompany the uploaded videos, but also by the virtual architecture of the exhibition space, the video castle. Carving out discursive spaces for queer, feminist, or lesbian 
subject positions, the video castle, with its cross-media setting, provides a framework of interpretation for online audiences, thereby contributing to the creation of transnational queer kinship groups celebrating a feminist audiovisual heritage.

\section{Towards a polyvocal LGBT+ heritage}

This essay has highlighted the various challenges archivists are facing in lesbian minor cinema archiving, focusing on issues of collection, circulation, and contextualization. While the need for preservation is urgent, there is also a great necessity to curate access to the digitized footage, because it is circulation rather than storage that creates memories. In this context it has become crucial to recontextualize the images. The archive thus 'becomes a place of recovery, a recuperative project of moving from silence to productive, transformative discourse. ${ }^{39}$ Contextualization can prevent lesbian images from being unqueered and thus being erased from LGBT + memory and heritage. The risk of unqueering archival footage leads to another question, which has not been addressed in this essay, but which is worth further discussion. ${ }^{40}$ Drawing on Johanna Schaffer's critical study of the ambivalences of visual representation, we could ask how archives can acknowledge minorities without reiterating and perpetuating their minority subject position. ${ }^{41}$ For minor archives, such as bildwechsel or the LHMP, this question is less relevant: founded in reaction to the omissions produced in other archives, minor archives deliberately foreground their minority position. For national archives, however, the question of ambivalent intent when representing minorities needs to be discussed and calls for further investigation.

Overall, lesbian home movie makers or film collectives need to be encouraged to entrust their footage to archives, especially ethnic minority, disabled, or working-class filmmakers. While the archive recently has become a buzzword in the arts and humanities, more theorization and research needs to be done, especially around the question of 'Whose Heritage is it?', to quote the title of a talk given 
by Stuart Hall in the late $1990{ }^{42}$ In it Hall criticized the notion of cultural heritage as inherently white and middle class. Film-making, after all, does not occur outside the power relations at work in society. As a result, rather than being a 'history from below', home movies have a rich history as a middle-class cultural practice. Instead of automatically offering counter-narratives, many home movies tend to tie in with hegemonic discourses. However, lesbian minor cinema is an intervention into film studies: it both challenges patriarchal notions of home movies as a predominantly male practice and it intervenes in the burgeoning research field on home movies, where LGBT+ film-making tends to be sidelined. I would argue that it would be too reductive to conceptualize the queer archive exclusively as an archive of trauma. While gays, lesbians, and transgender persons have indeed been criminalized and pathologized throughout history, LGBT+ home movies and amateur films are an important means to diversify the public narrative by showing LGBT + lives lived beyond the legal and medical discourses. Moreover, such film inscribes queers into the public sphere, into everyday life, into family life, into rural life, into regional landscapes, into city life, into festivities, into national holidays. In short, by queering the audiovisual memories circulating in society, they diversify the narratives of the past and so contribute to the polyvocality of cultural memory.

Luckily, archival projects have been teaming up to preserve LGBT+ film-making. The Outfest UCLA Legacy Project for LGBT Moving Image Preservation, founded in 2005, a collaboration between the Outfest Los Angeles LGBT Film Festival and the UCLA Film and Television Archive, has broken new ground in the restoration and renewed circulation of queer film classics, independent film productions, and home movie collections. ${ }^{43}$ Although more archival projects for the preservation of LGBT+ audiovisual heritage are currently emerging, especially in the US, further measures need to be taken to stop the global decay of analogue film footage and to ensure the sustainable preservation of our film heritage. ${ }^{44}$ As Pepe concludes, 'The preservation work by the community-based archives, the institutional archives, the 
studios, and the Legacy Project are significant steps to ensure the survival of important and endangered LGBT works, but the work still left to be done is endless. ${ }^{35}$

This essay has emphasized the agency of the archivist. While moving image archivists have often been conceptualized as gatekeepers who prevent access to fragile analogue film stock, digitization has turned them into enablers who provide access to the archival holdings. Another urgent question remains, though, especially for archivists in minor archives. How can their vast knowledge, often acquired over several decades, be passed on to a new generation? Cherishing 'the rich ties between generations that connect lesbian communities' is of vital importance to avoid the queerness 'transmitted covertly' (Muñoz) ending up on the road to oblivion. ${ }^{46}$

\section{Notes}

1 Ruth Storm Collection, Excerpt, C. 1938, Sharon Thompson, 25 June 2015, https://vimeo.com/131782501, in full at https://www.lesbianhomemovieproject. org/item/maine-i/.

2 See Thompson 2015, 114-16.

3 Thompson 2015,115 . Its collection now includes more than 500 films and tapes donated from all over the US. Note that for the purposes of this essay, the term 'LGBT+ heritage' will only refer to productions by, for and about LGBT+ audiences, but not including all those cinematic moments which have been appropriated by audiences through queer readings, and which therefore, undoubtedly, have become parts of LGBT+ heritage.

4 It is doubtful that digitization will be a sustainable means of preservation; parallel analogue restoration would be recommended. See Brunow 2017, 98-110.

5 Kirste 2007, 134-40; Olson 2001, 639-68.

6 Thompson 2015, 115.

7 See also Fossati 2009; Brunow 2017.

8 Muñoz 1996, 5-16; Cvetkovich 2003; Halberstam 2005; Morris 2006, 145-51; Danbolt 2010, 90-118; Marshall 2014, 1-11; Stone \& Cantrell 2015.

9 See Kirste 2007; Pepe 2011, 632-8; Thompson 2015.

10 Following Czach 2014, 27-37, I use home movies and amateur filmmaking as two sides to a continuum.

11 For an overview of the development of home movie research, see Rascaroli et al. 2014.

12 See Zimmermann 2008, 1-28; see also Smith 2018. 
13 Pepe 2011, 635.

14 Thompson 2015, 114.

15 Foucault 1972; Derrida 1996; Stoler 2002, 87-109. For a more detailed discussion of the notion of the 'archive', see Brunow 2015.

16 Marshall et al. 2014, 2.

17 Halberstam 2005, 169-70.

18 For references, see Brunow 2015; Andersson \& Sundholm 2017: 79-92.

19 Zimmermann 2008 has introduced the notion of polyvocality, based on theorizations by Robert Berkhofer, in the study of home movies.

20 See Brunow 2012, 171-82; Brunow 2015.

21 Thompson 2015, 115.

22 See ibid. Donors of analogue footage are not charged by the LHMP for its digitization, documentation and preservation. Instead, they get a digital copy in return.

23 Kirste 2007, 135.

24 For example, Erll \& Rigney 2009; De Cesari \& Rigney 2014; Brunow 2015.

25 https://www.lesbianhomemovieproject.org, accessed 1 March 2019.

26 Cvetkovich 2003. Kirste 2007, 136 provides a useful overview on the challenges of collecting and preserving films in moving image archives versus LGBT+ grassroots archives.

27 Thompson 2018.

28 Ibid.

29 See Brunow 2015.

30 Zimmermann 2008, 16.

31 Thompson $2015,115$.

32 I am referring here to viewing contexts rather than the reception by individual audience members. In the process of reception, as Stuart Hall (1999, 90-103) has outlined, the viewer can accept, oppose or negotiate not only the representation in the film, but also, I would add, the framework of interpretation provided by the industrial context of production, distribution, and exhibition.

33 Muñoz 1996, 6.

34 Ibid.

35 Kirste 2007, 136.

36 Hall 1999.

37 Brunow 2012 \& 2015. bildwechsel's founder durbahn has experimented with YouTube for the dissemination of own video clips, mainly those part of the 'video museum'. The video museum is another part of the archive's self-reflexive approach to archiving as an artist practice.

38 http://durbahn.net/videoschloss/, last access 20 February 2018. For more detailed descriptions, see Brunow 2015; Maule 2016, 381-400.

39 Stone \& Cantrell 2015, 3.

40 See Brunow 2018, 174-95.

41 Schaffer 2008. 
42 Hall 2002, 72-84.

43 https://www.cinema.ucla.edu/collections/outfest-ucla-legacy-project, last access 20 February 2018.

44 For example, LGBT + home movies are currently being digitized by the archives of the San Francisco GLBT Historical Society and the Metro Theatre Center Foundation, also based in San Francisco. Also the Lesbian Herstory Archives in New York have digitized some of their audiovisual collections, for example the Dyke TV collection and the Daughter of Bilitis Video Project.

45 Pepe 2011, 637.

46 Thompson $2015,114$.

\section{References}

Andersson, Lars Gustaf \& John Sundholm, 'The Cultural Practice of Minor Cinema Archiving: The Case of Immigrant Filmmakers in Sweden', Journal of Scandinavian Cinema (special issue 'Scandinavian cinema culture and archival practices: collecting, curating and accessing moving image histories', eds Dagmar Brunow \& Ingrid Stigsdotter), 7/2 (2017): 79-92.

Brunow, Dagmar, 'Before YouTube and Indymedia: Cultural Memory and the Archive of Video Collectives in Germany in the 1970s and 1980s', Studies in European Cinema 8/3 (2012): 171-82.

- - Remediating Transcultural Memory: Documentary Filmmaking as Archival Intervention (Berlin: De Gruyter, 2015).

- - 'Curating Access to Audiovisual Heritage: Transnational memory and polyvocality in European film archives', Image \& Narrative 18/1 (2017): 98-110.

- - 'Naming, shaming, framing? Ambivalence of queer visibility in audiovisual archives', in Anu Koivunen, Katariina Kyrölä \& Ingrid Ryberg (eds), The Power of Vulnerability: Mobilizing Affect in Feminist, Queer and Anti-racist Media Cultures (Manchester: MUP, 2018).

Cvetkovich, Ann, An Archive of Feelings: Trauma, Sexuality, and Lesbian Public Cultures (Durham: Duke University Press, 2003).

Czach, Liz, 'Home Movies and Amateur Film as National Cinema', in Rascaroli, Laura, Barry Monahan \& Gwenda Young (eds), Amateur Filmmaking: The Home Movie, the Archive, the Web (New York: Bloomsbury Academic, 2014).

Danbolt, Mathias, 'We're here! We're queer? Activist archives and archival activism, lambda nordica, 15/3-4 (2010): 90-118.

De Cesari, Chiara \& Ann Rigney (eds), Transnational Memory: Circulation, Articulation, Scales (Berlin: De Gruyter, 2014).

Deleuze, Gilles \& Felix Guattari, Kafka: Toward a minor literature, tr. Dana Polan (Minneapolis: University of Minnesota Press, 1986).

Derrida, Jacques, Archive Fever: A Freudian impression, tr. Eric Prenowitz (Chicago: University of Chicago Press, 1996). 
Erll, Astrid \& Ann Rigney (eds.), Mediation, Remediation, and the Dynamics of Cultural Memory (Berlin: De Gruyter, 2009).

Fossati, Giovanna, From Grain to Pixel: The Archival Life of Film in Transition (Amsterdam: AUP, 2009).

Foucault, Michel, The Archaeology of Knowledge (London: Routledge, 1972).

Halberstam, Judith [Jack], In a Queer Time and Place: Transgender Bodies, Subcultural Lives (New York: NYUP, 2005).

Hall, Stuart, 'Encoding, Decoding', in Simon During (ed.), The Cultural Studies Reader (London: Routledge, 1999): 90-103.

- - 'Whose Heritage? Un-settling "The Heritage", Re-imagining the Post-Nation', in Rasheed Araaen, Sean Cubitt \& Ziauddin Sardar (eds), The Third Text Reader on Art, Culture and Theory (London: Continuum, 2002) (first pub. 1999).

Kirste, Lynne, 'Collective Effort: Archiving LGBT+ Moving Images', Cinema Journal 46/3 (2007): 134-40.

Marshall, David, Kevin P. Murphy \& Zeb Tortorici, 'Editors' introduction: Queering archives: Intimate tracings', Radical History Review 122 (2014): 1-11.

Maule, Rosanna, 'Mobilizing women's art: bildwechsel, a global archive', European Journal of Women's Studies 23/4 (2016): 381-400.

Morris, Charles E., 'Archival Queer', Rhetoric \& Public Affairs 9/1 (2006): 145-51.

Muñoz, José Esteban, 'Ephemera as Evidence: Introductory Notes to Queer Acts', Women \& Performance: A Journal of Feminist Theory 8/2 (1996): 5-16.

Olson, Hope, 'The Power to Name: Representation in Library Catalogs', Signs, 26/3 (2001): 639-68.

Pepe, Kristin (KP), 'Outside the Hollywood Canon: Preserving Lesbian Moving Images', GLQ: A Journal of Lesbian \& Gay Studies 17/4 (2011): 632-8.

Rascaroli, Laura, Barry Monahan \& Gwenda Young (eds), Amateur Filmmaking: The Home Movie, the Archive, the Web (New York: Bloomsbury Academic, 2014).

Ruth Storm Collection, Excerpt, C. 1938, Sharon Thompson, 25 June 2015, https:// vimeo.com/131782501 [video].

Schaffer, Johanna, Ambivalenzen der Sichtbarkeit: Über die visuellen Strukturen der Anerkennung (Bielefeld: Transcript, 2008).

Smith, Ashley, The Archival Life of Home Movies: Regional Reflections and Negotiated Visions of a Shared Past (Diss., Stockholm: Department of Media Studies, Stockholm University, 2018).

Stoler, Ann Laura, 'Colonial archives and the Arts of Governance', Archival Science, 2/1-2 (2002): 87-109.

Stone, Amy L. \& Jaime Cantrell (eds.), Out of the Closet, into the Archives: Researching Sexual Histories (New York: Suny, 2015).

Thompson, Sharon, 'Urgent: The Lesbian Home Movie Project', Journal of Lesbian Studies, 19/1 (2015): 114-116.

- - 'The Archival Gets Personal', 13 April 2018, https://www.lesbianhomemovieproject.org/blog/, accessed 9 March 2019 [blog]. 
Zimmermann, Patricia, 'Introduction: The Home Movie Movement: Excavations, Artifacts, Minings', in K. L. Ishizuka \& P. R. Zimmermann (eds), Mining the Home Movie: Excavations in History and Memory (Berkeley \& Los Angeles: University of California Press, 2008). 